Indian Journal of Science and Technology

http://www.indjst.org

Vol.1 No.2 (Dec. 2007)

\title{
Light and transmission electron microscopic studies on conidiomata developmental morphology in Pestalotiopsis rhododendri
}

\author{
M. Murugan ${ }^{1}$, V. Gangadevi ${ }^{2}$ and J. Muthumary ${ }^{3 *}$ \\ Centre for Advanced Studies in Botany,
}

University of Madras, Guindy Campus, Chenna: 600 025, Tamil Nadu, India.

murubio2001@yahoo.com¹; vganges@yahoo.co.in ${ }^{2}$; Corresponding author: mm_j@rediffmail.com*

\begin{abstract}
Investigations on the development of conidiomata in Pestalotiopsis rhododendri (Saccardo) Guba were done by using light and Transmission electron microscopes. Light microscopic studies showed the presence of non-ostiolate, pycnidial conidiomata in culture. Acervular conidiomata are produced normally by species of Pestalotiopsis on leaves. The other interesting observation during the study was the ultrastructure of the conidial wall in the coloured cells as well as the basal and apical hyaline cells with the appendages. Pestalotiopsis rhododendri resembles $P$. uvicola in the development of conidiomata. The first time report of the various stages of development of conidiomata in Pestalotiopsis rhododendri will be useful in fungal systematic studies.
\end{abstract}

Keywords: Acervular conidiomata, Coelomycetes, conidium ontogeny, fungi, pycnidial conidiomata, ultrastructure.

Introduction

The conidiomata among Coelomycetes vary in their structure and therefore a system of classification based on conidiomatal types becomes difficult. Acervular, stromatic and pycnidial conidiomata are found in the species of Colletotrichum in culture. Similarly, conidiogenous cells are formed directly from the mycelium in culture though Coelomycets are known to produce pycnidial conidiomata in nature (Baxter, 1981; Baxter et al., 1985; Subramanian \& Reddy, 1974). The distinction between Hyphomycetes and Coelomycetes may have to be abandoned because of acervular, stromatic and cupulate conidiomata and several intermediatery stages are common for both groups. In the present investigation, it was observed that $P$. rhododendri produced pycnidial conidiomata when grown in culture and acervular conidiomata on natural hosts. The various stages of development of the conidiomata were investigated in culture and they also resembled that of a typical pycnidial conidioma, which are already studied. The developmental morphology of the conidiomata in $P$. rhododendri in culture is described here.

\section{Materials and Methods}

Pestalotiopsis rhododendri (Saccardo)

Guba was isolated from leaf of Rhododendron grande collected in Kodaikanal, Tamil Nadu, India, dated August 1995. Culture of $P$. rhododendri was grown on oat meal agar (OMA) and potato dextrose agar (PDA) in Petridishes at room temperature $\left(28^{\circ} \mathrm{C}\right)$. The initial stages of the development of conidiomatal primordia were studied by slide cultures (Riddell, 1950). For germination studies, conidia were collected aseptically from the teased out conidiomata in $1 \%$ glucose solution and allowed to germinate in cavity slides kept at room temperature $\left(28^{\circ} \mathrm{C}\right)$ and the germination pattern was examined for $36 \mathrm{~h}$ at every $5 \mathrm{~h}$ interval.

To study the development of conidiomata, selected conidiomata with agar were trimmed into $2 \mathrm{~mm}$ square blocks and fixed in $2 \%$ glutaraldehyde (Sigma) in $0.1 \mathrm{M}$ phosphate buffer $(\mathrm{pH} 7.2)$ for $2 \mathrm{~h}$ at room temperature $\left(27^{\circ} \mathrm{C}\right)$ and $1 \mathrm{~h}$ at $4^{\circ} \mathrm{C}$ and post fixed for $12 \mathrm{~h}$ in $1 \%$ osmium tetroxide (Sigma). Specimens were dehydrated through an ascending series of acetone $(30-100 \%)$ at room temperature, each change at $30 \mathrm{~min}$ intervals, followed by 2-3 changes in fresh Spurr in the ratio of 3:1 (Acetone: Spurr) for $6 \mathrm{~h}$, followed by two changes with absolute Spurr mixture for $24 \mathrm{~h}$ each lasting for $8 \mathrm{~h}$ and polymerised in fresh Spurr at $70^{\circ} \mathrm{C}$ for $8 \mathrm{~h}$. Semi-thin sections $(0.5 \mu \mathrm{m})$ were cut through ultramicrotome (Reichert-Jung) from these blocks and stained with $1 \%$ aqueous toluidine blue (Sigma) to study the development of conidiomata and conidiogenesis under the light microscope (Nikon "Labophot" model HFX11). Ultrathin sections were collected on 400 mesh copper girds (Sigma) and excess water in the grids was removed by filter paper. Photomicrographs (Kodak film, Sigma) were taken using a transmission electron micrographs (Philips CM 10) at 40 and $60 \mathrm{KV}$.

Results

Description of the fungus in culture: Conidiomata acervular, numerous, pustules disc-shaped, 300-420 $\mu \mathrm{m}$ in diam. The fruiting bodies were filled up with numerous conidia, 
bearing long appendages. Conidia longfusiform, elliptic-clavate, slightly curved, 5celled, 22-26 (24) X 6-8 (6.0) $\mu \mathrm{m}$, the three intermediate cells were brown in colour, 15-18 $x 7.5 \mu \mathrm{m}$, the upper two dark brown, often swollen, the lowest coloured cell light brown, constricted at the septa, apical cells hyaline, long cylindrical, bearing 3 appendages, basal cells broad conic, 2-7.5 $\mu \mathrm{m}$ with a single, straight appendage. Apical appendages 16-20 (16.5) $\mu \mathrm{m}$, basal appendage 4-6 (4.5) $\mu \mathrm{m}$ (Fig. 1).

Development of conidiomatal initial: The germination study showed that the conidia became swollen when resulted in the breakage of outer wall and the germ tube emerged. The germ tubes mainly arise from the lower most median cells. One to two germ tubes arise from each cell (Fig.2). The conidiomatal initials were first evident as small knots of fungal hyphae. Some of the cells became swollen and thickwalled and multiply by repeated divisions to form the knot-like primordium. This type of primordium formation is referred to as "meristogenous type"(Fig. 3). The primordium is also initiated by "symphogenous type" where the cells of adjacent hyphae by continued cross and longitudinal divisions, form the primordium. Also, intertwining of several hyphae resulted in primordia formation. Initially the cells constituting the primordium are spherical to subspherical and are hyaline which stain deeply when compared to the cells of the surrounding hyphae (Fig. 4). During further development the primordium continuously increased in size by continued transverse and longitudinal divisions of the cells. As the primordial initials increase in size, the several layers of the promordium became differentiated into morphologically distinct layers. The outermost one or two layers were pseudoparenchymatous with thick, lightly pigmented walls, which form the outer wall layer of the conidiomata (Fig. 5). Inside this outer wall there were three to four compact layer of cells.

Formation of cavity and sporogenous tissue: The central cells in the primordium showed signs of schizogenous and lysigenous activity to form the central cavity. Further developmental stages showed the formation of the conidium simultaneously with the cavity formation (Fig. 5). As the conidia nature they are released from the conidiogenous cells are fill up the cavity (Fig. 6) The conidioma become flattened in shape during the later stages of development. The mature conidioma produces conidiogenous cells which line only the flattened basal region but not the sides and upper region of the condioma (Figs. 7, 8).

Dehiscence of conidioma to release the conidia: There is no regularly formed ostiole found in this species. After maturity the upper layers of the conidioma open quite irregularly to release the conidia.

\section{Electron Microscopical Studies}

Conidiogenous cells and conidia: The initial of the conidium arises as a small protrusion of the apex of the conidiogeous cell (Fig. 9) and develops holoblastically. Cell organelles migrate into the developing conidium until a delimiting septum is formed more or less near the base of the conidium initial. As conidium enlarges, the conidium wall forms an electronopaque outer layer, which starts from the base of the conidium. The inner transparent layer of the conidium is continuous with the wall of the conidiogenous cell. The conidiogenous cell itself does not develop an electron-opaque outer wall layer. Successive conidium develops from a point just at or below the level at which the preceding conidium was delimited. The conidia were produced from the annellides and more than 3 annellations were observed in some conidiogenous cells. Sections through the young conidiomata showed that the conidia arise from spherical to subspherical conidiogenous cells lining their cavity (Fig. 10, 11).

\section{Discussion}

The present study reported for the first time the various stages of development of conidiomata in Pestalotiopsis rhododendri. Sutton (1961) has reported the various stages in conidial development with reference to some species of Pestalotiopsis. The fungus is known to produce only acervular conidiomata on its host, however, in artificial culture media, pycnidial conidiomata were observed. Very interestingly, the fungus produces initially temporary conidiomata with very few conidia before any well developed wall layers are formed. As soon as the conidiomatal initial is formed, certain cells at the centre of the pseudoparenchymatous primordium give rise to conidia. The conidioma thus formed are only 1-2 layered. It was very difficult to determine whether the conidia thus produced are different from those produced inside mature conidiomata later. In Pestalotiopsis sydowiana, two morphologically distinct adult spore types were recoded i.e., a) spores with two umber superior cells and a dark brown septum separating them and b) spores with 
two fuliginous superior cells and a very dark brown to black septum separating them. In it the difference in the conidial type was interpreted to the fact that the first conidia might be quite distinct from the second and third conidia, which were formed from
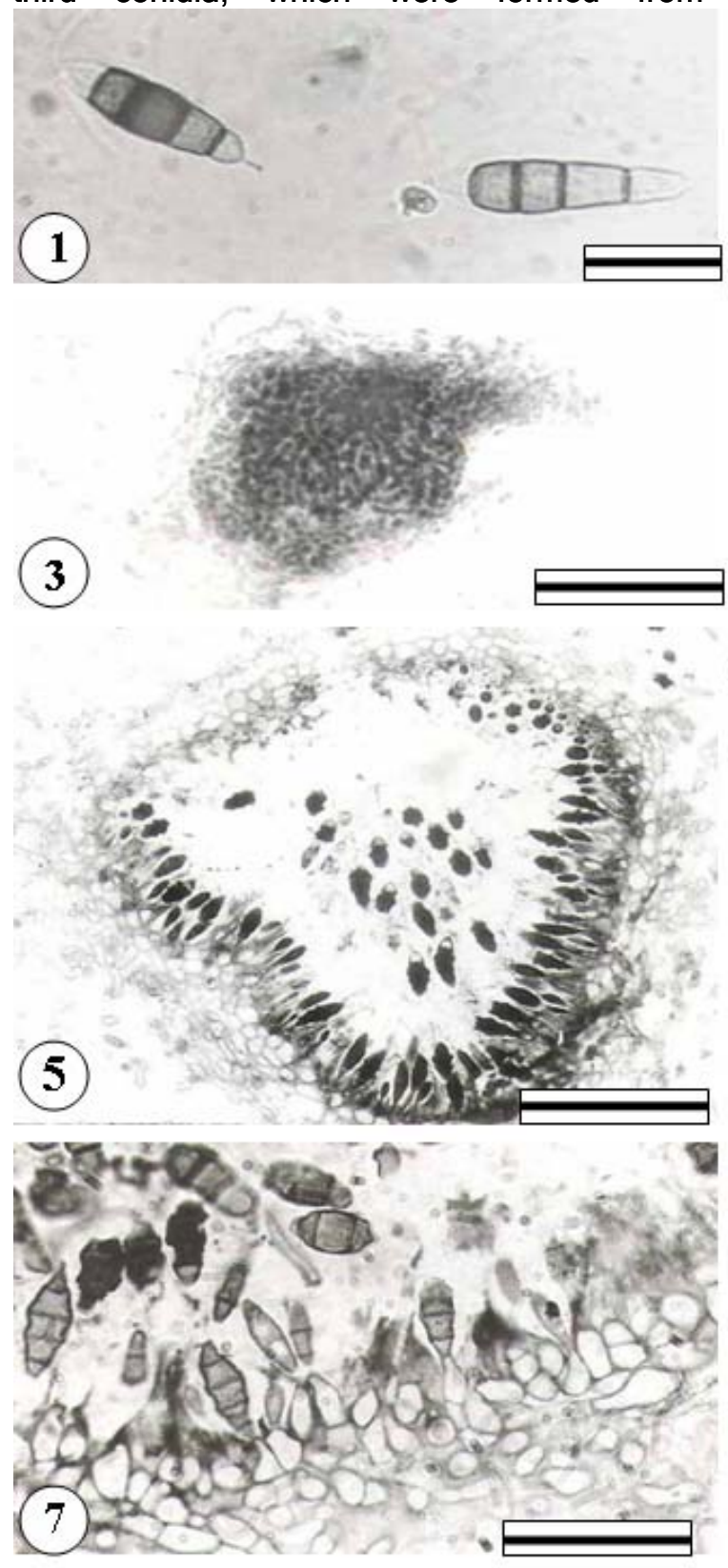

successive proliferations (Sutton, 1961). But in the present investigation it was observed that initially conidiogenous cells are not annellides because the first formed conidia (primary conidia) are holoblastic and only during the
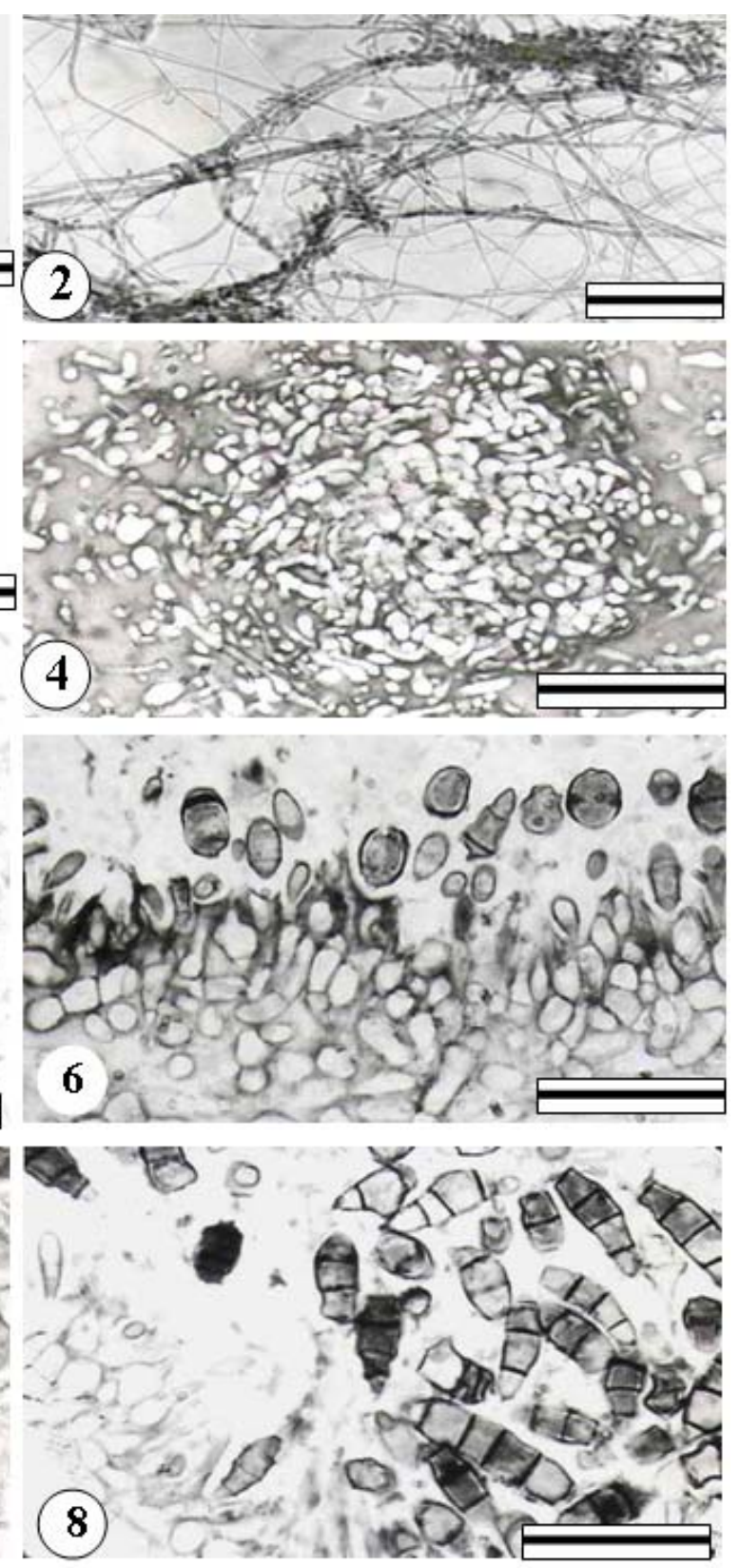

1. Mature conidia. Bar $=12.5 \mu \mathrm{m} ; 2$. Compound meristogenous methods of conidiomatal formation, Bar $=100 \mu \mathrm{m} ; 3$. Temporary conidiomatal formation, Bar $=25 \mu \mathrm{m} ; 4$. Section of a young conidiomatal initials showing pseudoparenchymatous tissue, Bar $=50 \mu \mathrm{m} ; 5$. Vertical section through primordia showing the dissolution of temporary conidiogenous cells, Bar $=100 \mu \mathrm{m} ; 6$. Sections showing temporary conidiogenous cells lining the conidiomatal cavity, Bar $=50 \mu \mathrm{m} ; 7$. Section of the conidioma showing temporary conidiogenous cells, Bar $=50 \mu \mathrm{m}$; 8. Section through conidiomata showing the released conidia, Bar $=50 \mu \mathrm{m}$.

later stages of development of the conidiomata secondary conidia are formed enteroblastically showing annellidic conidiogenesis. Later on the conidiogenous cells or annellides are formed which are cylindrical with 4-5 annellations. This shows that the first formed 
conidia might be morphologically different from the secondary conidia formed successively from the conidiogenous cell. The dual conidiation process was also observed in other

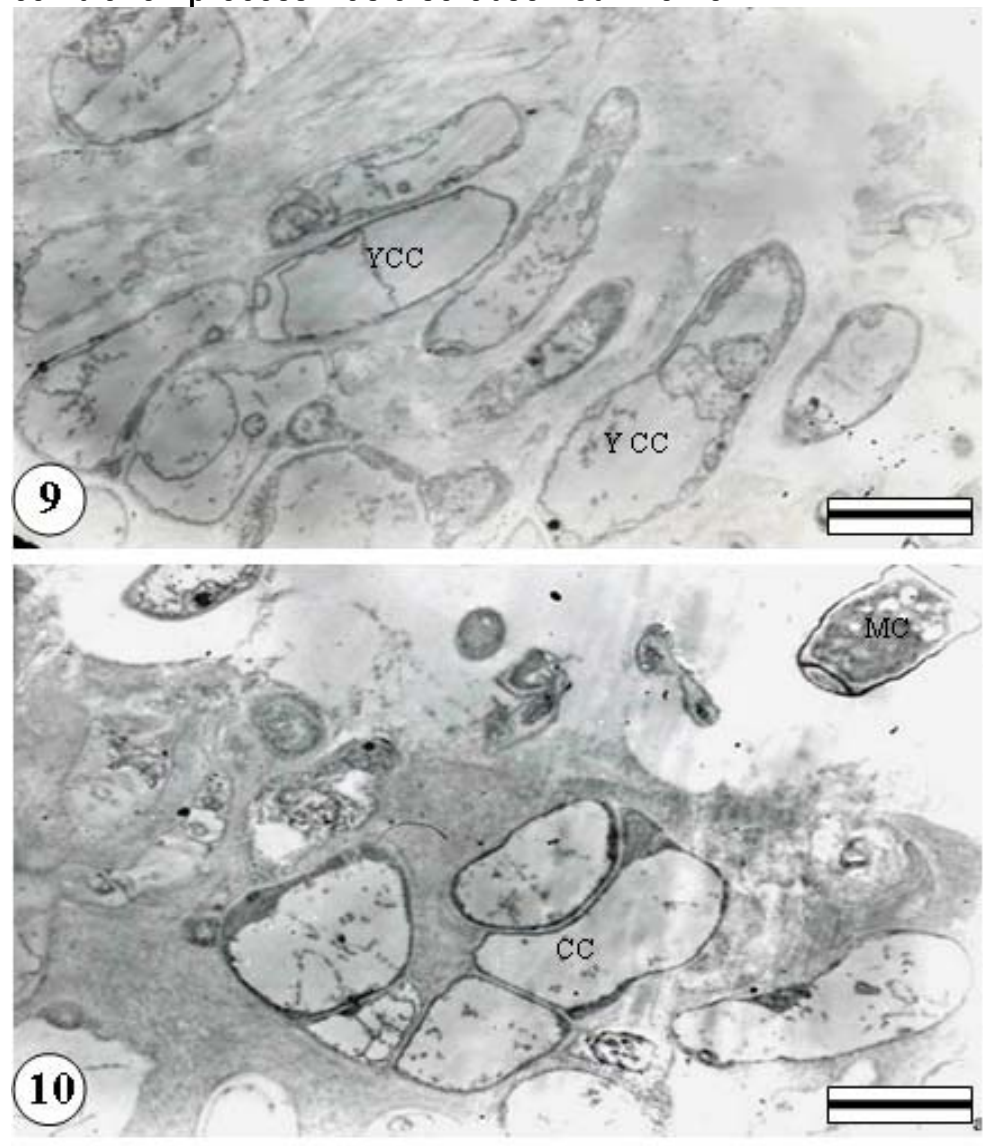

species of Pestalotiopsis from this lab. In addition, there is another type of conidiomatal formation from primordial initials.

\section{Transmission Electron microscopic of conidiogenous cell. Section through young conidiogenous cells, Bar = $1 \mu$ m; 10. TEM of conidiogenous cell. Section through young conidiogenous cells with young conidia, Bar = $1 \mu \mathrm{m}$; 11. TEM of conidiogenous cell. Section of dividing conidiogenous cells with conidium, Bar $=2 \mu \mathrm{m}$. \\ YCC=Young Conidiogenous cell, CC=Condiogenous cell, YC=Young conidium, MC=Mature conidium}

As the primordium increases in size, the central cavity is to be formed because the primordium is a compactly packed pseudoparenchymatous tissue. The central cells in the primordium showed signs of schizogenous and lysigenous activity to form the central cavity. The remaining portions of the cells of the primordium often gelatinise and fill up the cavity with the mucilagenous matrix. Probably, the matrix provides nutrition to the developing conidiogenous cells and young conidia. Nag Raj (1981) suggested that the slime, which originates through lysis occurring during cavity formation, plays an important role in conidium dispersal. The slimy matrix also plays an indirect role in the dispersal of the conidia by insects. It was also observed that in $P$. cruenta, the disorganized central cells of the primordium gelatinise to form the slimy matrix. In $P$. disseminata, the formation of the slimy matrix inside the cavity was not very clearly observed. In the present study on P.rhododendri the temporary conidiogenous cells showed signs of degeneration inside the cavity after releasing the conidia. The formation of a slimy matrix by the dissolution of central cells of the primordia was not very clear in $P$. bicolor and $P$. cruenta. Pestalotiopsis uvicola resembles $P$. rhododendri in that the temporary conidiogenous cells showed degenerative activity after releasing the conidia into the cavity.

From the above observations, it is clear that Pestalotiopsis species in our investigation showed the presence of mucilagenous matrix, arising either through lysis during cavity formation or formed by the degenerating temporary conidiogenous cells which play an important role in the survival of the fungus. The presence of mucilagenous 
matrix during the formation of the pycnidial conidiomata was reported in certain other pycnidial Coelomycetes also (Masilamani \& Muthumary 1994, 1995, 1996; Murugan \& Muthumary 2001, 2003). The formation of temporary and permanent conidiogenous cells inside the cavity of the conidiomata is another interesting feature studied in species of Pestalotiopsis. It was the pioneering work of Punithalingam (1979) who studied in detail, the process of conidiation in Ascochyta species in culture. The production of temporary and permanent conidiogenous cells in Ascochyta is construed as a general feature of Ascochyta species in culture (Punithalingam, 1979). Similarly, the dual conidiation process was observed by us in Pestalotiopsis rhododendri. The dual conidiation process was also observed in Phyllosticta caryota when grown in culture. Punithalingam (1979) reported that some of the observations made with Ascochyta in culture were in conformity with the interpretations of Archer (1926) during his investigation of cavity formation and ostiole development in some members of Sphaeropsidales. This suggests that probably these fungi, which produce pycnidial conidiomata in culture, follow some specific regularity in their conidiomatal development. However, it is not possible to conclude that these stages of developmental processes occur during the formation of the pycnidia on various host plants in natural habitat.

The fine structure of the conidiogenous cells and conidia were demonstrated in four Coelomycete species (Campbell, 1968; Griffiths \& Swart, 1974 a, b; Sutton \& Sandhu, 1969). Generally, these studies were intended to extend light microscopic observations. Some of the features, which could not be resolved adequately by the light microscope, could be demonstrated with the help of electron microscope. Obviously, in the present investigation, the fine structural details observed with the electron microscope in Pestalotiopsis rhododendri have demonstrated some interesting findings. Longitudinal sections through the conidia of Pestalotiopsis rhododendri showed massive and highly pigmented conidial walls. The transverse septa vary in the degree of pigmentation, perhaps, due to the varying sequences of development within the maturing conidium. The conidial wall is characterized by the deposition of electron dense material in the outer layers of the septa. The basal and apical cells have partly pigmented and partly unpigmented walls, which are clearly distinct from the central cells. Externally, the conidia are sheathed in an electron-dense outer wall and an electron-transparent inner wall. The conidial cells showed perforation between individual cells by a simple septal pore. The conidial wall consists of an outer layer bounding an inner layer, which consists of a finely granular matrix. According to Griffiths and Swart (1974a) in Pestalotiopsis, the conidial wall is single-layered though differentiated into an outer melanized zone and a much thicker, inner hyaline zone. Sutton (1969) on the basis of light microscopy suggested that they are two distinct wall layers - the outer pigmented and the inner, nonpigmented. It is true that it is not possible to observe melanization of a portion of a thin cell wall by light microscopy. But mycologists hold different views regarding the accurate description of the wall layers in Pestalotiopsis. Therefore, Griffiths and Swart (1974a) described the pigmented and non-pigmented areas of the wall as "zones" rather than "layers".

In the present investigation, following Sutton (1969) the outer melanized wall and the hyaline inner wall layer are treated separately. The conidium in Pestalotiopsis has an outer electron-dense layer and an inner electron transparent layer in the wall. The thicknesses of the two wall layers differ in that the median cells have a thick inner wall layer and a thin outer wall layer when compared to the end cells of the conidium. According to Griffiths and Swart (1974a), during septation of the conidium, the peripheral zone of the conidial wall becomes electron dense, by the deposition of melanin in the wall matrix while the remaining portion of the wall remains hyaline. Therefore, they concluded that the outer zone of the wall is melanized while the inner zone remains unpigmented. The transconidial septa arise as outgrowths of the conidial wall and new wall material is deposited external to the invaginations of the plasma membrane. In mature conidia the transconidial septum consists of a thin, central, electron dense layer flanked on either side by a hyaline layer. A distinct pore formed centrally, following cessation of wall material deposition perforates the septum. When all the four septa are formed, the conidium consists of the pigmented peripheral walls and the transconidial septa. The well-pronounced wrinkling observed in the outer-pigmented wall of the lowermost median cell implies that it is 
Indian Journal of Science and Technology

structurally different from the rest of the cells. Griffiths and Swart (1974a) noticed that this lower most median cell is frequently binucleate and is characterized by the presence of large round, electron-dense particles within the hyaline wall layer. The apical and basal cells, which are hyaline morphologically, were indistinguishable from the median cells at the ultrastructural level. During the later stages of development, the end cells undergo cytolysis and in mature conidia are devoid of cytoplasmic contents. Cytolysis occurs very soon in the apical cell since it bears the appendages and only during the later stages in the basal hyaline cell because of its attachment to the conidiogenous cell. The conidia are produced from annellides and up to five anellations were observed. The basal appendage of the developing conidium was sometimes observed within the annellide. The basal cell along with the appendage remained viable long after the cytolysis of the apical cell.

Acknowledgements

We thankfully remember late Prof.Dr. A.Mehadevan, Former Director, Centre for Advanced studies in Botany, University of Madras, Chennai for the facilities provided. We thank the U.G.C. for financial assistance.

\section{References}

1. Archer WA (1926) Morphological characters of some Sphaeropsidales in culture. Ann Mycol. 24, 1-84.

2. Baxter AP (1981) A study of the morphology and taxonomy of certain South African species of Colletotrichum corda. M.Sc. Thesis, University of Pretoria, Pretoria, South Africa.

3. Baxter AP, Van Der Westhuizen GCA and Eicker A (1985) A review of literature on the taxonomy, morphology and biology of the fungal genus Colletotrichum. Phytophylactica. 17, 15-18.

4. Campbell R (1968) An electron microscope study of spore structure and development in Alternaria brassicicola. J. Gen. Microbiol. 54, 381-392.

5. conidiomata in Pestalotiopsis uvicola with a note on the ultrastructure of the conidia and conidiogenous cell. J. Mycol. Pl. Pathol. 33 (2), 204-211.

6. Griffiths DA and Swart HJ (1974a) Conidial structure in two species of Pestalotiopsis. Trans Br Mycol Soc. 62(2), 295-304.

7. Griffiths DA and Swart HJ (1974b) Conidial structure in Pestalotia pezizoides. Trans $\mathrm{Br}$ Mycol Soc. 63(1), 169-173. http://www.indjst.org Vol.1 No.2 (Dec. 2007)

8. Masilamani S and Muthumary J (1995) Pycnidium ontogeny in Coleophoma cylindrospora. Mycol Res. 99(6), 693-969.

9. Masilamani S and Muthumary J (1994) Development of Conidiomata in Ciliochorella mangiferae (Coelomycetes) Mycol Res. 98(8), 857-861.

10. Masilamani S and Muthumary J (1996) Development of conidiomata in Botryodiplodia theobromae Mycol Res. 100(11), 1383-1387.

11. Murugan $\mathrm{M}$ and Muthumary $\mathrm{J}$ (2001) Developmental morphology and ultrastructure of Pestalotiopsis maculans. Mycotaxon. 79, 55 - 465.

12. Murugan $\mathrm{M}$ and Muthumary $\mathrm{J}$ (2003) Studies on developmental morphology of the

13. Nag Raj TR (1981) Coelomycete Systematics. In Biology of conidial Fungi I (ed. G.T. Cole and B. Kendrick). Academic Press. New York. Nag Raj TR (1993) Coelomycetous anamorphs with appendage - bearing conidia. Mycologue publications 331 Daleview PI. Wateloo, Ontario, Canada N2L 5M5. pp. 43-79.

14. Punithalingam E (1979) Graminicolous Ascochyta species. Commonwealth Mycological Institute. Mycol. pp. 142.

15. Riddell RB (1950) Permanent stained mycological preparations obtained by slide cultures. Mycologia. 42, 265-270.

16. Subramanian CV and Reddy KRC (1974) The genus Discosia I. Taxonomy. Kavaka 2, 57-89.

17. Sutton BC (1961) Coelomycetes. I Mycol. pp. 80, 1-16.

18. Sutton BC (1969) Forest microfungi III. The heterogenecity of Pestalotia de Not. Section Sexloculatae Klebahn sensu Guba. Can J Bot. 48, 2083-2094.

19. Sutton BC and Sandhu DK (1969) Electron Microscopy of conidium development and secession in Cryptosporiopsis sp., Phoma fumosa, Melanconium bicolor and $M$. apiocarpum. Can J Bot. 47, 745-749. 